University of Nebraska - Lincoln

DigitalCommons@University of Nebraska - Lincoln

To Improve the Academy

Professional and Organizational Development Network in Higher Education

1995

Faculty Development Programs at Research Universities:

Implications for Senior Faculty Renewal

Arthur L. Crawley

Follow this and additional works at: https://digitalcommons.unl.edu/podimproveacad

Part of the Higher Education Administration Commons

Crawley, Arthur L., "Faculty Development Programs at Research Universities: Implications for Senior Faculty Renewal" (1995). To Improve the Academy. 330.

https://digitalcommons.unl.edu/podimproveacad/330

This Article is brought to you for free and open access by the Professional and Organizational Development Network in Higher Education at DigitalCommons@University of Nebraska - Lincoln. It has been accepted for inclusion in To Improve the Academy by an authorized administrator of DigitalCommons@University of Nebraska - Lincoln. 


\section{Faculty Development Programs at Research Universities: Implications for Senior Faculty Renewal}

\section{Dr. Arthur L. Crawley}

This article examines the research findings from that portion of the National Survey on Senior Faculty Renewal which pertains to the faculty development programs available to senior faculty at research universities in support of their career development and renewal. Survey respondents were coordinators and directors of faculty development programs and selected academic affairs administrators with faculty development responsibilities at their respective institutions. In general, the findings reveal a high level of support for the traditional approaches to faculty development for senior faculty in the context of their teaching and research. However, the findings suggest that faculty development approaches that are targeted to enhance senior faculty careers by either expanding employment options or by creating new roles and responsibilities are more limited. Additional findings concern the availability of post-retirement options, opportunities for collaborative work, and incentives to encourage excellence in teaching, research, and service.

Today, tenured faculty members, 50 years of age or older, constitute approximately half of the full-time faculty at colleges and universities across the United States. The likelihood is that a significant number 
of senior faculty will continue to be employed at their respective institutions well into the next century (El-Khawas, 1991; Rice \& Finklestein, 1993). Research universities have a distinctive experience in this regard. On average, their faculty are older and more tenured when compared to other higher education institutions (National Center for Educational Statistics, 1990). In addition, there is recent evidence that faculty at research universities retire at later ages than faculty at other institutions (Lozier \& Dooris, 1991).

As of January 1, 1994, colleges and universities are no longer permitted to mandate the retirement of tenured faculty on the basis of age alone (Franke, 1993). Some fear that with the abolishment of the mandatory retirement age, a disproportionate number of senior faculty will continue occupying tenured positions past the age of 70 , and past their ability to perform their scholarly and teaching roles effectively (Bader, 1988; Crawley, 1990). Since the overwhelming research evidence demonstrates that an increase in the average age of faculty does not necessarily affect institutional quality (Hammond \& Morgan, 1991), the concerns expressed are largely unjustified and may represent an undercurrent of age bias in the academic workplace (Crawley, 1995). The extensive research on aging and faculty productivity confirms that "faculty in their 70s can continue to perform well and that there are variations in performance among faculty at any age" (Hammond \& Morgan, 1991, p. 105).

Although the general consensus on the abolishment of compulsory retirement for tenured faculty suggests that there will be no substantial negative consequences for the majority of colleges and universities, the National Research Council's Committee on Mandatory Retirement in Higher Education (Hammond \& Morgan, 1991) concluded that "at some research universities a high proportion of faculty would choose to remain employed past age 70 if allowed to do so" (p. 2). The Committee expressed concern that without mandatory retirement some research universities would likely suffer both increased costs and limited flexibility to hire new faculty.

When examining the aging and career profile of current faculty, an additional factor provides for further uncertainty with regard to faculty seniority and mandatory retirement issues - a rapidly changing academic labor market. Schuster (1990a) predicts a more active job 
market after the mid-1990s. His forecast is based on the expected widespread retirement of faculty hired in the 1960 s and the increase in college enrollments predicted by demographers. He believes that competition will become intense for quality faculty within the next few years, creating a situation far more fluid and dynamic than experienced in the academic marketplace for some time.

Schuster (1990a) dramatically calls attention to the interconnectedness of these critical issues as leading to a "bipolar" faculty - simultaneous employment of large cohorts of younger and older faculty -that will pose extraordinary challenges to higher education well into the next century. Schuster believes that the imbalances that may result could adversely affect faculty performance, morale, and institutional quality.

Schuster (1990b) chastises the inadequate efforts of research universities with their "unparalleled repositories of knowledge about the management and development of human resources" (p. 14) in meeting the personal and professional development needs of their own faculty. Schuster believes that "campuses in general appear to have failed to take into adequate account the changing demographic and environmental factors that shape faculty careers" (p. 15). He encourages colleges and universities to pay more attention to the nature and amount of resources that will be needed to support all facets of faculty work: teaching, research, and service; the environmental factors that encourage the best integration of the three; and, the opportunity and reward structures that foster a willingness among faculty to improve both teaching and research skills. He calls for campus-based, faculty development programs to specifically target the personal and professional needs of both the most senior (experienced) and the most junior (inexperienced) faculty.

Finkelstein and Jemmott (1993) liken senior faculty to village elders of the past who "having attained status and stature in their villages by virtue of longevity, experience, and wisdom, played central roles in upholding traditions, socializing the young, and maintaining the culture of the village" (p. 95). Senior faculty as repositors of the campus mores, values, and culture have a unique role to play in the socialization of the next generation of faculty. Baldwin and Blackburn (1983) view faculty as versatile, human resources. Senior faculty, 
those who have served their profession, their disciplines, and their institutions for many years should not be seen as any less so.

\section{Purpose of the Study}

Appropriate institutional responses to enhance the careers of senior faculty while expanding their retirement options are an increasingly important concern in higher education. Both faculty seniority and the end of mandatory retirement for tenured faculty have broad policy implications that will affect not only future decisions regarding faculty staffing needs, but also will call for innovative approaches to maintain a productive senior faculty as well as to provide for a dignified retirement.

Heretofore, there has been little empirical research on the scope or nature of the programmatic response to the growing cohort of senior faculty that cannot be forced to retire; nor on the academic policies needed to maintain a quality senior faculty during a time of diminishing supply and increasing demand for faculty (Western Interstate Commission for Higher Education, 1992). The purpose of this research study was to expand our knowledge of faculty development programs and policies at research universities and their implications for senior faculty career development and renewal.

\section{Research Methodology}

This descriptive study was carried out as a survey research project using an instrument developed by the researcher titled the National Survey on Senior Faculty Renewal. ${ }^{1}$ The survey items were generated from four primary sources: (a) a thorough review of the literature on faculty development and renewal; (b) previous national surveys and reports on faculty development programs, faculty retirement projections, faculty supply and demand, faculty productivity and aging, and

\footnotetext{
${ }^{1}$ The National Survey on Senior Faculty Renewal consists of three sections. This article discusses the findings from Section A: Program Initiatives. Two additional articles cover the results obtained from Section B: Policy Initiatives (see Crawley, in press) and Section C: Mandatory Retirement Issues (see Crawley, 1995). A copy of the survey instrument can be obtained from the author.
} 
mandatory retirement issues; (c) a brainstorming session and discussion with five coordinators/ directors of faculty development programs as part of a conference presentation on mandatory retirement and faculty seniority issues during a regional faculty development conference in 1991; and, (d) a pilot study during the Summer of 1992 with six coordinators/ directors of faculty development.

The study was conducted during the Winter of 1992-1993. The survey respondents were coordinators and directors of faculty development programs, and selected academic affairs administrators with faculty development responsibilities at their respective institutions. These survey respondents served as institutional informants representing each of the 104 research universities as classified by the Carnegie Foundation for the Advancement of Teaching (1987).

In the first section of the National Survey on Senior Faculty Renewal, survey respondents were asked to indicate by checking the appropriate box if each of 67 program initiatives was currently in use at their universities; and, if not in use, was future use planned by January 1,1994 . If the program initiative was neither currently in use, nor planned by January 1, 1994, respondents were asked to check the box labelled "neither." The survey respondents were also instructed that, to be considered currently in use, program initiatives should have been generally available to senior faculty at their institutions within the previous 12 months.

Because of the extended length of the survey, it was not feasible to request additional information from the respondents concerning their estimation of the use or effectiveness of these program initiatives. Also, information on the amount or type of funding and staffing available, needed, or anticipated was not requested. These questions should be asked and would be fertile ground for future research.

Eighty-one completed surveys were returned. The survey response rate was $77.9 \%$. Of the 81 surveys returned, $80(98.8 \%)$ of the surveys were satisfactorily completed and used for data analysis. Table 1 presents descriptive data on selected institutional variables for the population of research universities surveyed $(N=104)$ and for the surveys used in analysis $(N=80)$. 


\begin{tabular}{|c|c|c|c|c|}
\hline \multicolumn{5}{|c|}{$\begin{array}{c}\text { TABLE I } \\
\text { Description of the Survey Population of Research } \\
\text { Universities and Survey Used by } \\
\text { Selected Institutional Variables }\end{array}$} \\
\hline \multirow[t]{2}{*}{$\begin{array}{l}\text { Institutional } \\
\text { Variable }\end{array}$} & \multicolumn{2}{|c|}{$\begin{array}{l}\text { Survey } \\
\text { Population } \\
(N=104)\end{array}$} & \multicolumn{2}{|c|}{$\begin{array}{c}\text { Surveys } \\
\text { Used for Analysis } \\
(N=80)\end{array}$} \\
\hline & $n$ & $\%$ & $n$ & $\%$ \\
\hline \multicolumn{5}{|l|}{ University Control } \\
\hline Public & 71 & 68.3 & 60 & 75.0 \\
\hline Private & 33 & 31.7 & 20 & 25.0 \\
\hline \multicolumn{5}{|l|}{ Classification } \\
\hline Research (1) & 70 & 67.3 & 52 & 65.0 \\
\hline Research (2) & 34 & 32.7 & 28 & 35.0 \\
\hline \multicolumn{5}{|l|}{ Geographical Region } \\
\hline Northeast & 27 & 26.0 & 20 & 25.0 \\
\hline North Central & 22 & 21.2 & 16 & 20.0 \\
\hline South & 31 & 28.8 & 24 & 30.0 \\
\hline West & 24 & 23.1 & 20 & 25.0 \\
\hline $\begin{array}{l}\text { Director/Coordinator for } \\
\text { Faculty/Instructional Development }\end{array}$ & 67 & 64.4 & 58 & 72.5 \\
\hline \multicolumn{5}{|c|}{$\begin{array}{l}\text { Note. Northeast includes CT, MA, NJ, NY, PA, RI; North Central-IA, IL, IN, KS, MI, MN, } \\
\text { MO, NE, OH, WI; South-AL, DC, DE, FL, GA, KY, LA, MD, MS, NC, OK, SC, TN, TX, VA, } \\
\text { WW; West-AZ, CA, CO, HI, NM, OR, UT, WA, WY. }\end{array}$} \\
\hline
\end{tabular}

\section{Research Findings and Analysis}

In order to facilitate the analysis of the data, the 67 program initiatives were grouped into six categories: (a) Faculty Career Development and Redirection, (b) Faculty Grants and Awards, (c) Faculty Collaboration and Collegiality, (d) Faculty In-Service Education, (e) Expert Faculty Consultation and Assistance, and (f) Senior Faculty Retirement. These six categories reflect Wheeler and Schuster's (1990) call for an enhanced definition of faculty development which integrates various aspects of the individual faculty career within the framework of organizational expectations. 


\section{TABLE II}

Availability of Program Initiatives Related to Faculty Career Development and Redirection at Research Universities $\left(N=80^{\mathrm{a}}\right)$

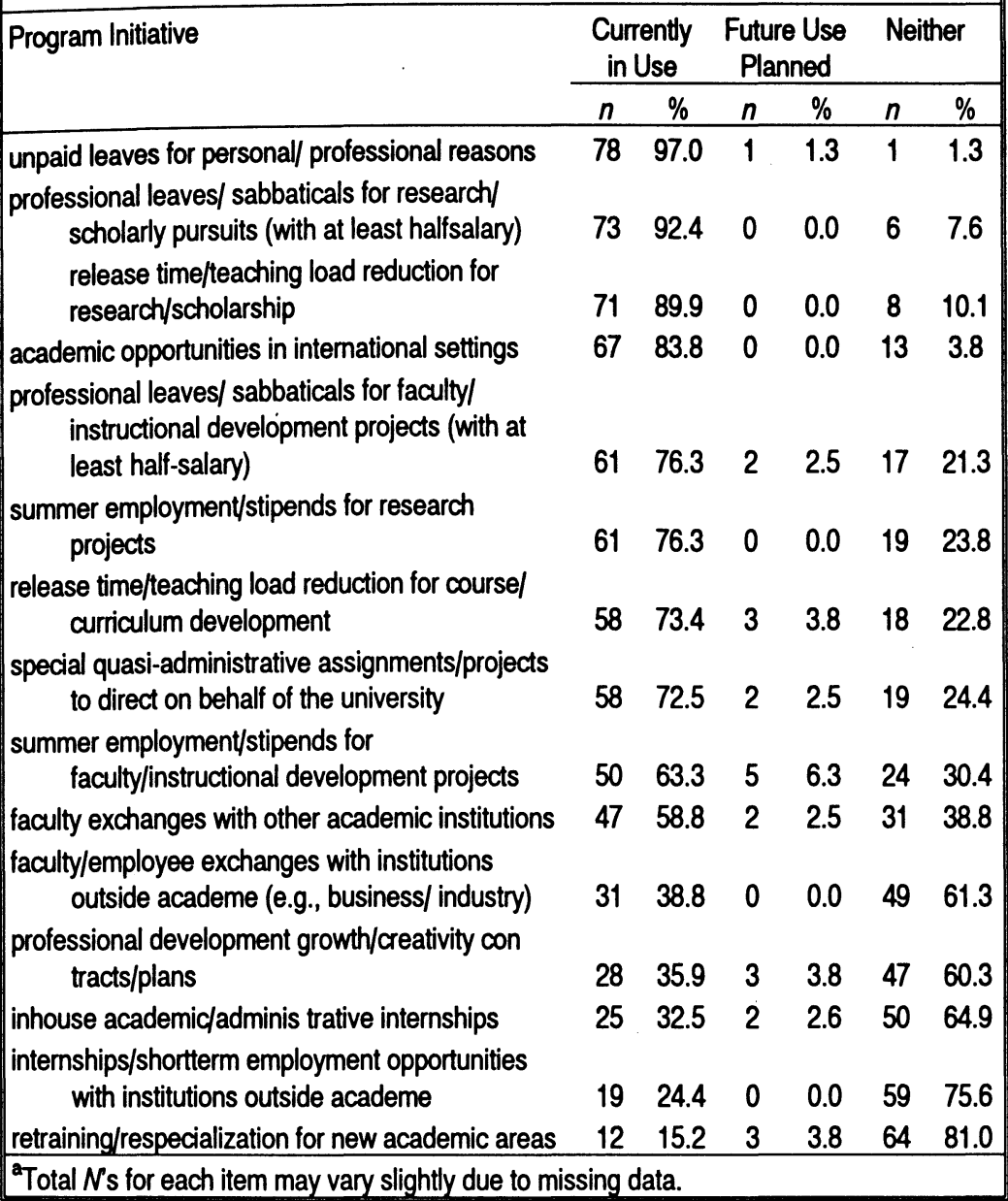

\section{Faculty Career Development and Redirection}

The program category of faculty career development and redirection consists of 15 initiatives. Table 2 lists those program initiatives 
which are currently in use and planned at research universities that expand the career options of faculty. The most frequently reported faculty development initiative in this category was unpaid leaves for personalprofessional reasons (97.5\%). This finding was not surprising given that such leaves require little in the way of additional cost to the institution and are relatively easy to administer. Likewise, not unexpected was the finding that traditional program initiatives which support scholarly pursuits were consistently more available to senior faculty than those which support instructional efforts. For example, $76.3 \%$ of the survey respondents reported that summer employment/stipends for research projects were currently available at their research universities, whereas only $63.3 \%$ of the survey respondents reported that summer employment/stipends for faculty/instructional development projects were currently available at their research universities.

A similar pattern prevailed when comparing release time/ teaching load reduction for research/scholarship (89.9\%) with release time/teaching load reduction for course/curriculum development (73.4\%), and professional leaves/sabbaticals for research/scholarly pursuits (with at least half-salary) (92.4\%) with professional leaves/sabbaticals for faculty/instructional development projects (with at least half-salary) (76.3\%). However, the six program initiatives, whether primarily in support of teaching or of research, were reported as currently available at a substantial majority of these research universities.

Although these survey findings suggest that a majority of research universities support their senior faculty in their teaching and research roles, additional findings suggest that program initiatives which attempt to enhance senior faculty careers by either expanding career options or by creating new roles and responsibilities are more limited. Only three of the eight program initiatives that promote senior faculty renewal, academic opportunities in international settings (83.8\%), special quasi-administrative assignments/projects to direct on behalf of the university (72.5\%), and faculty exchanges with other academic institutions (58.8\%) were reported as being currently available at a majority of the research universities. 
The remaining five program initiatives were reported as currently available at only a minority of research universities with little prospect of any substantially planned increase in their use: faculty/employee exchanges with institutions outside academe (e.g. business/industry) (38.8\%), professional development growth/creativity contracts/plans (35.9\%), in-house academic/ administrative internships (32.5\%), internships/short-term employment opportunities with institutions outside academe (24.4\%), and retraining/respecialization for new academic areas $(15.2 \%)$.

\section{Faculty Grants and Awards}

The program category of faculty grants and awards includes 11 initiatives. These program initiatives support or reward faculty, often monetarily, in their tripartite academic responsibilities of teaching, research, and service. As shown in Table 3,10 of the 11 program initiatives were currently offered by more than half of the research universities responding. Not surprisingly, the traditional approach of rewarding long and scholarly careers through endowed chairs/distinguished professorships $(98.8 \%$ ) achieved the highest percentage of current use.

As with the prior category of program initiatives, those initiatives which support research were reported as generally more available to senior faculty than those initiatives which support teaching. For example, research funds/grants to pursue scholarly interests were currently available at $92.4 \%$ of the responding research universities, whereas faculty/instructional development funds/grants to enhance teaching/develop courses were available at $78.8 \%$ of the responding research universities. Likewise, travel funds/grants to attend conferences/programs to enhance research skills/scholarship were currently available at $86.3 \%$ of research universities responding, whereas travel funds/grants to attend conferences/programs to enhance teaching/leadership skills were currently available at $73.4 \%$ of research universities responding. 


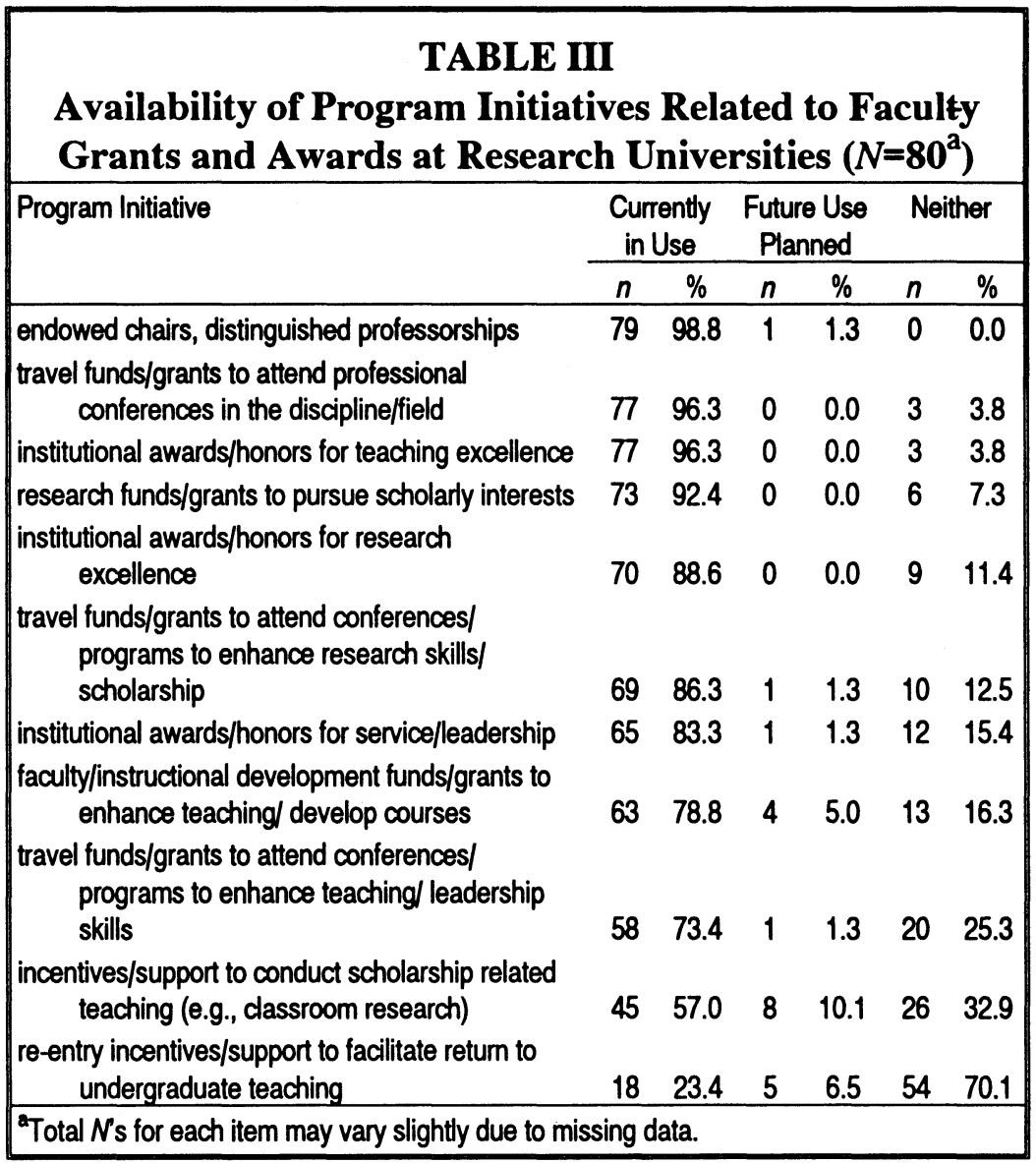

The ascendancy of the academic discipline at research universities, as part and parcel of the academic culture, was apparent in the high level of support for travel funds/grants to attend professional conferences in the discipline/field (96.3\%) which outdistanced all similar funds available in support of improving either teaching or research skills. However, with regard to the current availability of institutional awards/honors for research, teaching, and service, the findings proved to be counter-intuitive. The availability of institutional awards/honors for teaching excellence (96.3\%) was greater than 
both institutional awards/honors for research excellence (88.6\%) and institutional awards/honors for service/leadership (83.3\%).

Another unexpected finding was that $57 \%$ of the survey respondents reported a program initiative currently in use to provide senior faculty incentives/support to conduct scholarship related to teaching (e.g., classroom research). An additional $10.1 \%$ of the respondents indicated that such incentives were to be made available by January 1, 1994.

Although teaching and service may not have parity in terms of recognition and rewards with research at most research universities, all program initiatives within this category which support or reward teaching and service were currently available at a majority of the research universities responding, except one. The one exception was re-entry incentives/support to facilitate senior faculty return to undergraduate teaching (23.4\%).

\section{Faculty Collaboration and Collegiality}

The lack of opportunities for faculty collaboration in the contemporary research university has been the lament of many academics (Astin \& Baldwin, 1991). The research findings, however, indicate that the availability of collaborative opportunities for senior faculty at research universities, as presented in Table 4, is quite substantial. Eleven of the 12 program initiatives from the category of faculty collaboration and collegiality were currently available by half or more of the research universities participating in the study.

Survey findings indicated only small percentage variations among the following initiatives: interdisciplinary/collaborative research/scholarly opportunities (89.7\%), interdisciplinary/ collaborative teaching/curricular opportunities (85.0\%), and leadership opportunities as part of university governance structure (84.8\%). Each of these three program initiatives represents an important faculty activity that closely parallels the traditional teaching, research, and service paradigm of expected faculty roles and responsibilities within the academic community. Furthermore, given the high percentage of the responding research universities that provide opportunities for involvement in graduate teaching assistants training/orientation 
(91.3\%), and mentoring opportunities with junior faculty (81.3\%), there appears to be a growing recognition of the need to recruit and to prepare the next generation of faculty members.

\begin{tabular}{|c|c|c|c|c|c|c|}
\hline $\begin{array}{l}\text { TABLE I } \\
\text { Availability of Program Initiat } \\
\text { Collaboration and Collegiality }\end{array}$ & $\begin{array}{l}\text { es } \\
\mathbf{R}\end{array}$ & ses & ch & $\begin{array}{l}\text { o Fr } \\
\text { nive }\end{array}$ & $\begin{array}{l}\text { cul } \\
\text { rsit }\end{array}$ & \\
\hline Program Initiative & & ently & & $\begin{array}{l}\text { Use } \\
\text { eed }\end{array}$ & & ther \\
\hline & $n$ & $\%$ & $n$ & $\%$ & $n$ & $\%$ \\
\hline $\begin{array}{l}\text { opportunities for involvement in graduate teaching } \\
\text { assistants training/ orientation }\end{array}$ & 73 & 91.3 & 2 & 2.5 & 5 & 6.3 \\
\hline $\begin{array}{l}\text { opportunities for the interchange of ideas with } \\
\text { visiting scholars/experts }\end{array}$ & 72 & 90.0 & 1 & 1.3 & 7 & 8.8 \\
\hline $\begin{array}{l}\text { interdisciplinary/ collaborative research/scholarly } \\
\text { opportunities }\end{array}$ & 70 & 89.7 & 0 & 0.0 & 8 & 10.3 \\
\hline $\begin{array}{l}\text { interdisciplinary/ collaborative teaching/ curricular } \\
\text { opportunities }\end{array}$ & 68 & 85.0 & 1 & 1.3 & 11 & 13.8 \\
\hline $\begin{array}{l}\text { leadership opportunities as part of university } \\
\text { governance structure }\end{array}$ & 67 & 84.8 & 0 & 0.0 & 12 & 15.2 \\
\hline mentoring opportunities with junior faculty & 65 & 81.3 & 6 & 7.5 & 9 & 11.3 \\
\hline $\begin{array}{l}\text { university-wide/inter departmental lecturing } \\
\text { opportunities }\end{array}$ & 62 & 80.5 & 1 & 1.3 & 14 & 18.2 \\
\hline $\begin{array}{l}\text { incentives for student faculty research/ } \\
\text { colleagueship }\end{array}$ & 53 & 68.8 & 4 & 5.2 & 20 & 26.0 \\
\hline $\begin{array}{l}\text { in-house publication opportunities on teaching/ } \\
\text { scholarly efforts (e.g., monographs/ } \\
\text { newsletters) }\end{array}$ & 53 & 66.3 & 3 & 3.8 & 24 & 30.0 \\
\hline $\begin{array}{l}\text { opportunities to present in-service educational } \\
\text { programs to fellow faculty }\end{array}$ & 52 & 65.8 & 2 & 2.5 & 25 & 31.6 \\
\hline consulting opportunities within the university & 44 & 58.7 & 0 & 0.0 & 31 & 41.3 \\
\hline $\begin{array}{l}\text { networking/interest groups to discuss shared } \\
\text { issues/concerns }\end{array}$ & 33 & 41.3 & 3 & 3.8 & 44 & 55.0 \\
\hline
\end{tabular}

Other avenues for faculty collaboration reported to be currently available to senior faculty at a majority of the responding research universities included opportunities for the interchange of ideas with visiting scholars/experts (90.0\%), university-wide/interdepartmental 
lecturing opportunities (80.5\%), incentives for student-faculty research/colleagueship (68.8\%), in-house publication opportunities on teaching/scholarly efforts (e.g., monographs/newsletters) (66.3\%), opportunities to present in-service educational programs to fellow faculty (65.8\%), and consulting opportunities within the university (58.7\%). The only program initiative within this category reported as currently not in use by a majority of research universities was networking/interest groups to discuss shared issues/concerns (41.3\%).

\section{Faculty Inservice Education}

The program category of faculty in-service education includes eight initiatives. Table 5 outlines the current and future use of in-house educational activities which promote the personal and professional development of faculty at research universities.

Workshops are among the most common in-service activities sponsored through faculty development offices (Erickson, 1986). The findings of this study show that workshops/seminars on teaching effectiveness/instructional issues (85\%) had the highest percentage of availability as an in-service activity at research universities, closely followed by pre-retirement education/ planning ( $84.6 \%$ ), a program initiative of particular importance to senior faculty nearing retirement, and health/wellness related workshops/activities (73.1\%), a program initiative which has been found increasingly important in maintaining the vitality of senior faculty (North, 1991). In addition, survey respondents reported a somewhat lower percentage of research universities currently making available a library/resource room containing educational materials on faculty/instructional development (67.5\%) and workshops/seminars to strengthen research skills/scholarly writing for publication (55.1\%).

There appears to be less interest in providing organizationalleadership development workshops/training (51.9\%) and personal/career development workshops/seminars(48.1\%). These two findings may reflect Baldwin's (1984, p. 51) concern that senior faculty may be "overlooked for future career development opportunities" given that they are nearing the traditional retirement age. 


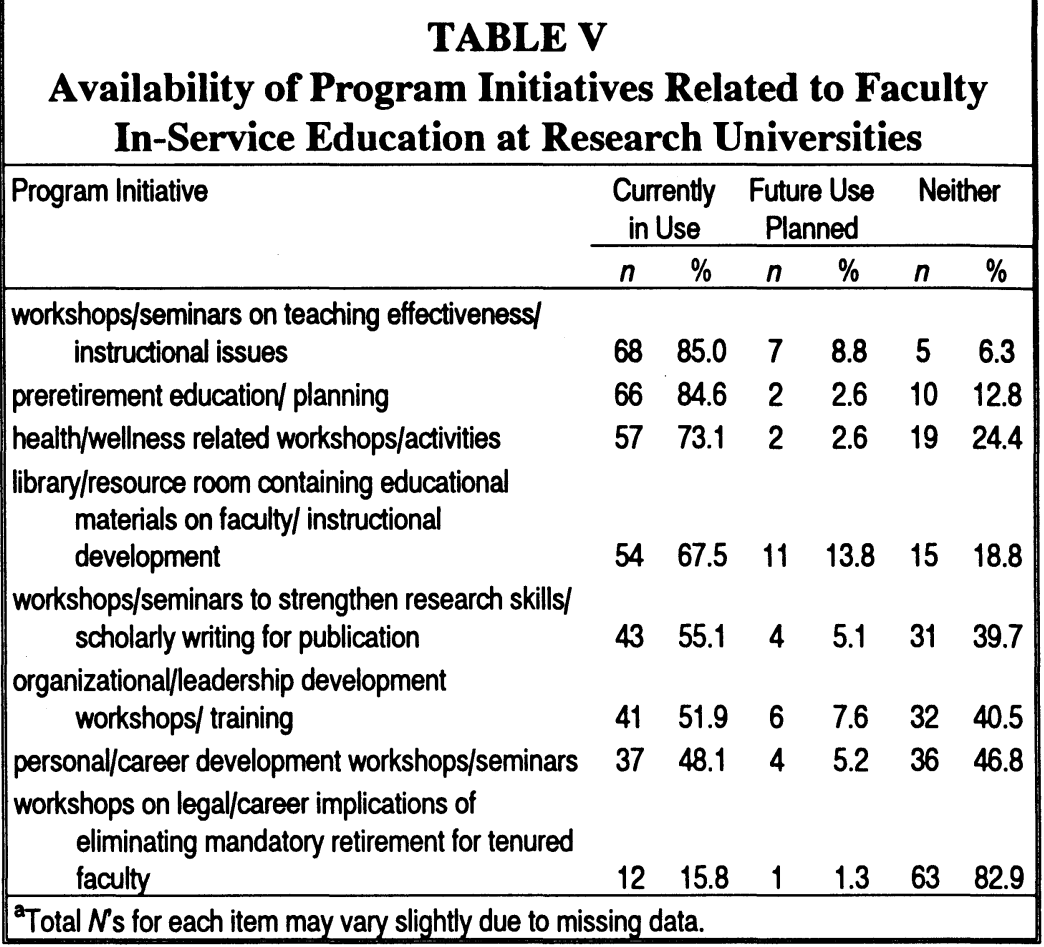

There was even less interest shown in offering workshops on the legal/career implications of eliminating mandatory retirement for tenured faculty. Only $15.8 \%$ of the survey respondents indicated that their universities had offered such workshops in the previous 12 months, and only one additional respondent reporting such workshops being planned by January 1, 1994.

\section{Expert Faculty Consultation and Assistance}

The program category of expert faculty consultation and assistance contains 12 initiatives. Table 6 outlines the current and future use of in-house faculty consultants at research universities. These consultants provide face-to-face assistance to faculty on a broad range of personal and professional concerns. 


\section{TABLE VI}

Availability of Program Initiatives Related to Expert Faculty Consultation and Assistance at Research Universities

\begin{tabular}{|c|c|c|c|c|c|c|}
\hline \multirow[t]{2}{*}{ Program Initiative } & \multicolumn{2}{|c|}{$\begin{array}{l}\text { Currently } \\
\text { in Use }\end{array}$} & \multicolumn{2}{|c|}{$\begin{array}{l}\text { Future Use } \\
\text { Planned }\end{array}$} & \multicolumn{2}{|c|}{ Neither } \\
\hline & $n$ & $\%$ & $n$ & $\%$ & $n$ & $\%$ \\
\hline $\begin{array}{l}\text { employee assistance counseling for substance } \\
\text { abuse/personal problems that impair job } \\
\text { performance }\end{array}$ & 70 & 89.7 & 0 & 0.0 & 8 & 10.3 \\
\hline $\begin{array}{l}\text { expert assistance on obtaining externally } \\
\text { sponsored fellowships/grants }\end{array}$ & 67 & 84.8 & 2 & 2.5 & 10 & 12.7 \\
\hline $\begin{array}{l}\text { individual teaching consultation/evaluation by } \\
\text { peer/expert for developmental purposes }\end{array}$ & 61 & 76.3 & 11 & 13.8 & 8 & 10.0 \\
\hline $\begin{array}{l}\text { expert consultation on using instructional } \\
\text { technologies/media development }\end{array}$ & 58 & 72.5 & 9 & 11.3 & 13 & 16.3 \\
\hline $\begin{array}{l}\text { expert assistance on the marketing of research/ } \\
\text { technological innovations }\end{array}$ & 49 & 63.6 & 3 & 3.9 & 25 & 32.5 \\
\hline $\begin{array}{l}\text { expert consultation on course/curriculum } \\
\text { development }\end{array}$ & 48 & 60.0 & 7 & 8.8 & 25 & 31.3 \\
\hline $\begin{array}{l}\text { expert consultation on improving research skills/ } \\
\text { scholarly writing for publication }\end{array}$ & 38 & 49.4 & 4 & 5.2 & 35 & 45.5 \\
\hline $\begin{array}{l}\text { expert consultation on developing professional } \\
\text { dossier/teaching portfolio }\end{array}$ & 36 & 45.6 & 15 & 19.0 & 28 & 35.4 \\
\hline $\begin{array}{l}\text { expert career consultation on } \\
\text { personal/professional goals }\end{array}$ & 16 & 20.8 & 1 & 1.3 & 60 & 77.9 \\
\hline $\begin{array}{l}\text { expert assistance on securing external } \\
\text { consultancies }\end{array}$ & 12 & 16.0 & 0 & 0.0 & 63 & 84.0 \\
\hline $\begin{array}{l}\text { outplacement assistance to explore nonacademic } \\
\text { work opportunities with guarantee of returm }\end{array}$ & 8 & 11.1 & 1 & 1.4 & 63 & 87.5 \\
\hline outplacement assistance when leaving academe & 8 & 11.1 & 1 & 1.4 & 63 & 87.5 \\
\hline
\end{tabular}

Surprisingly, given its recent emergence in the faculty development literature (Hosokawa, 1990), employee assistance counseling for substance abuse/personal problems that impair job performance was currently available at $89.7 \%$ of the research universities participating in the study. Long-standing, more traditional consultation services, were also in use by a high percentage of the responding research 
universities: expert assistance on obtaining externally sponsored fellowships/grants (84.8\%), individual teaching consultation/evaluation by peer/expert for developmental purposes (76.3\%), expert consultation on using instructional technologies/media development (72.5\%), expert assistance on marketing of research/technological innovations (63.6\%), and expert consultation on course/curriculum development $(60 \%)$. Two additional program initiatives in this category, expert consultation on developing a professional dossier/teaching portfolio and expert consultation on improving research skills/scholarly writing for publication, do achieve majority status, $64.6 \%$ and $54.6 \%$ respectively, when you add in those research universities that plan to make available such consulting services by January 1, 1994.

The extremely low availability of the remaining four initiatives, expert career consultation on personalprofessional goals (20.8\%), expert assistance on securing external consultancies (16.0\%), outplacement assistance to explore non-academic work opportunities with guarantee of return (11.1\%), and out-placement assistance when leaving academe $(11.1 \%)$ may indicate a failure at most of the responding research universities to provide expert assistance to their senior faculty for the purpose of career reexamination. This seems to be particularly the case with regard to expanding career options for senior faculty outside of academe.

\section{Senior Faculty Retirement}

The program category of senior faculty retirement, as presented in Table 7, contains nine initiatives which foster preand postretirement options and opportunities for latecareer faculty. Not having a mandatory retirement age for tenured faculty members appears to have brought home to most research universities the importance of expanding their post-retirement opportunities for senior faculty. Currently, various post-retirement opportunities were in use by a high percentage of research universities participating in this study: post-retirement privileges (e.g., office space) (92.4\%), post-retirement contract employment for specific tasks/projects (84.8\%), post-retirement volunteer service/leadership opportunities $(74.4 \%)$, post-retirement 
employment opportunities without the loss of benefits (66.2\%), and a post-retirement faculty association/organization (64.6\%).

\begin{tabular}{|c|c|c|c|c|c|c|}
\hline \multicolumn{7}{|c|}{$\begin{array}{l}\text { TABLE VII } \\
\text { Availability of Program Initiatives Related to Senior } \\
\text { Faculty Retirement at Research Universities }\end{array}$} \\
\hline \multirow[t]{2}{*}{ Program Initiative } & \multicolumn{2}{|c|}{$\begin{array}{l}\text { Currently } \\
\text { in Use }\end{array}$} & \multicolumn{2}{|c|}{$\begin{array}{l}\text { Future Use } \\
\text { Planned }\end{array}$} & \multicolumn{2}{|c|}{ Neither } \\
\hline & $n$ & $\%$ & $n$ & $\%$ & $n$ & $\%$ \\
\hline post-retirement privileges (e.g., office space) & 73 & 92.4 & 1 & 1.3 & 5 & 6.3 \\
\hline $\begin{array}{l}\text { post-retirement contract employment for specific } \\
\text { tasks/projects }\end{array}$ & 67 & 84.8 & 2 & 2.5 & 10 & 12.7 \\
\hline phased/partial retirement options & 64 & 83.1 & 2 & 2.6 & 11 & 14.5 \\
\hline $\begin{array}{l}\text { post-retirement volunteer service/leadership } \\
\text { opportunities }\end{array}$ & 58 & 74.4 & 2 & 2.6 & 18 & 23.1 \\
\hline early retirement incentive options & 57 & 73.1 & 7 & 9.0 & 14 & 17.9 \\
\hline $\begin{array}{l}\text { post-retirement employment opportunities without } \\
\text { the loss of benefits }\end{array}$ & 49 & 66.2 & 3 & 4.1 & 22 & 29.7 \\
\hline post-retirement faculty association/organization & 51 & 64.6 & 3 & 3.8 & 25 & 31.6 \\
\hline $\begin{array}{l}\text { post-retirement support to continue professional/ } \\
\text { scholarly activities (e.g., special projects fund) }\end{array}$ & 36 & 47.4 & 2 & 2.6 & 38 & 50.0 \\
\hline $\begin{array}{l}\text { post-retirement center/ senior academy for life } \\
\text { long learning }\end{array}$ & 16 & 20.3 & 3 & 3.8 & 60 & 75.9 \\
\hline
\end{tabular}

The lure of early retirement incentive options as a means of conserving faculty positions remains high among the research universities surveyed, as well. Almost three-quarters (73.1\%) of responding research universities currently make such options available to their senior faculty. In addition, $\mathbf{8 3 . 1 \%}$ of the research universities reported offering phased/partial retirement options which permit faculty to move more gradually into retirement. Only two post-retirement opportunities were not currently provided by a majority of research universities participating in the study: post-retirement support to continue professional/scholarly activities (e.g., special projects fund (47.4\%), and a post-retirement center/senior academy for lifelong learning (20.3\%). 


\section{Discussion}

By most accounts, until very recently the attention to teaching at research universities had been one of benign neglect (Centra, 1993). However, a powerful movement apparently is underway at many research universities to restore teaching to its rightful place in partnership with research. Several survey findings lend empirical evidence to this dramatic shift in the ground rules defining what it means to be an academic at research universities.

First, the establishment of a means for documenting and evaluating teaching effectiveness using teaching portfolios is gaining increasing acceptance at a majority of the research universities surveyed. Previous research by Seldin (1993) reported an increase since 1988 in the number of four-year institutions using teaching portfolios from 10 to 400 , out of more than 600 institutions, or two-thirds of institutions surveyed. In this survey, the number of research universities which were currently using teaching portfolios, or were planning on using them by 1994, approached a similar proportion. Teaching portfolios provide a way of documenting teaching effectiveness that opens the classroom door onto one's teaching and, as an added benefit, encourages a view of teaching as a scholarly activity (Seldin, 1991).

Second, the increase in the percentage of research universities providing individual consultation to improve teaching for developmental purposes is additional evidence of such a movement. Previous research indicated that approximately $60 \%$ of public and private universities in 1985 provided instructional consultation assistance (Erickson, 1986). When this survey was conducted in the Winter of 1992-93, over three-quarters of the respondents reported that their universities provided such assistance. If you add those respondents who indicated that their universities plan to have such assistance available by 1994 , the percentage increases dramatically to $90 \%$. Long regarded as a mainstay of many faculty development programs (Lewis \& Povlacs, 1988), the practice of face-to-face consultation to improve teaching effectiveness has apparently become a permanent fixture at most research universities.

Third, the survey results show that more research universities are providing incentives for preparing faculty in the scholarship of teach- 
ing as recommended by Boyer (1990). For example, nearly $70 \%$ of responding research universities reported having, or planning to have by 1994, programs to provide senior faculty incentives/support to conduct scholarship related to teaching.

Furthermore, program initiatives which support instructional or curricular efforts were reported as being available at a higher percentage than previous research findings on the availability of the same or similar faculty development practices during the 1970s and 1980s (Centra, 1976; Erickson, 1986; Kurfiss \& Boice, 1990). Likewise, the popularity of traditional faculty grants and awards remains high. Taken as a group, nearly $80 \%$ of the survey respondents said their research universities offered these program initiatives to their senior faculty: a higher percentage than any other category of program initiatives. In addition, within the program category of faculty in-service education, workshops/ seminars on teaching effectiveness and related instructional issues continue to enjoy high popularity. Over $90 \%$ of the responding research institutions currently have, or plan to have by the beginning of 1994, such workshops/seminars on their campuses.

Teaching awards remain a mainstay of many faculty development programs as a means of fostering teaching improvement even though their effectiveness in doing so has been questioned (Centra, 1993). However, as Centra concedes, teaching awards do have "symbolic value" (p. 13): they signal to important internal and external constituencies an institution's commitment to teaching in the face of the research imperative. This may explain why the availability of teaching awards on an institutional level outdistanced research awards.

Although there is an apparent increase in the efforts made by research universities in support of senior faculty as scholarly teachers, the findings suggest that faculty development approaches that are targeted to enhance senior faculty careers by creating new roles and responsibilities remain more limited. There still appears to be present on the vast majority of research campuses the "one career, one life" imperative for faculty, thereby discouraging career re-examination or expansion on their part. For example, retraining/respecialization for new academic areas was reported as currently available at less than one in seven research universities. 
Moreover, programs that focus on career assessment and planning, such as professional growth contracting and career consulting assistance, were found to be currently available at a limited number of research universities. Opportunities for in-house academic internships and short-term employment opportunities outside academe were available at less than one in three of the responding research universities. Such career opportunities can help a senior faculty member to gradually phase into retirement or into another career after formal retirement from academe.

Nearly three-quarters of the research universities reported that they provided some form of early or phased retirement program. However, the use of early retirement options, once considered the mainstay of encouraging faculty turnover in times of retrenchment, is not without its critics. Chronister (1990) believes that incentive early retirement options "based solely on strategies that facilitate the turnover of faculty may be viewed as shortsighted and counterproductive in the long term" (p. 159). He cites research findings that suggest that "colleges and universities are losing faculty members who could have continued to make significant contributions to institutional vitality" (p. 159).

Of considerable importance to senior faculty nearing retirement was the finding that many research universities have expanded their post-retirement opportunities including providing support for scholarly and service activities. Such programs make the retirement years more attractive as a career destination for senior faculty as well as providing opportunities for retired faculty to make constructive contributions to their university, their profession, and to society in general.

Somewhat unexpected was the little interest in offering workshops on the legal/career implications of eliminating mandatory retirement for tenured faculty. Given the possibility of legal action and the need for selecting from various retirement incentive programs, such workshops could prove useful in providing adequate career direction for senior faculty while avoiding potential age discrimination litigation against the institution (Craver, 1990).

Personal concerns such as substance abuse that may result in the need for professional counseling services is apparently being addressed by more research universities. Heretofore, personal counsel- 
ing services were often considered outside the province of most faculty development programs conceptually and in practice (Centra, 1976; Erickson, 1986). In like manner, the research results clearly indicate an increased emphasis in retirement education and health and wellness related programming. Currently over three-quarters of survey respondents indicated that their universities provide such programs. These findings may indicate that personal development within a context of enhanced faculty development, as advocated by Wheeler and Schuster (1990), is becoming more of a reality as faculty development programs mature on research campuses.

Just as research universities appear to be more responsive to the "high touch" needs of their senior faculty, they likewise appear to be increasingly responsive to their "high tech" needs. Nearly three-quarters of the responding research universities currently provide expert consultation to their senior faculty on the use of technological innovations for instructional and scholarly pursuits. Computer anxiety is a common experience among many faculty, regardless of age. Also, it takes time for faculty to adjust to rapid changes brought about by technological innovations. Important to the acceptance by faculty of new technologies is the development of a support system that provides time and a safe environment for faculty to explore a wide range of new education and information technologies (Albright \& Graf, 1992).

Research has shown that one of the key factors distinguishing faculty who remain vital throughout their careers is that vital faculty seek out collaborative activities with colleagues (Astin \& Baldwin, 1991). Contrary to much of the published literature, an overwhelming majority of survey respondents reported that their institutions were making available collaborative opportunities for teaching, curricular, and research efforts.

An important collaborative opportunity, which is currently available at more than $80 \%$ of the research universities responding to this survey, is mentoring programs. Research has shown that both parties in a mentoring relationship can benefit from the experience (Boice, 1992). Junior faculty are helped in arranging needed supports and resources which are beneficial in establishing the base for further academic career success. Many senior faculty have found the mentoring experience to be an important time for rethinking and redirecting 
their own careers and strengthening their sense of belonging and community. The need for developing minority and women faculty may be giving mentoring a new role as well (Blackwell, 1989; Johnsrud, 1994).

An additional collaborative opportunity available to senior faculty is in the training of the faculty of the future. As part of the reform movement in higher education to "resuscitate teaching" (Schuster, 1993, p. 29) and improve undergraduate education, graduate teaching assistant training programs have grown rapidly in the last 10 years. $\mathrm{A}$ large number of university campuses have their training programs in place, staffed and housed within faculty development offices or centers (Nyquist, Abbott, \& Wulff, 1989). The survey results show that over $90 \%$ of research universities provide opportunities for senior faculty to be involved in the training of graduate teaching assistants.

One indicator of the health of faculty development on university campuses is the number of individuals designated as directors and coordinators of faculty or instructional development. As of the Winter of 1992-93, when this survey was conducted, $64.4 \%$ of research universities were found to have a person designated as the director or coordinator of faculty/ instructional development (see Table 1).

Exact comparison data to previous research on the percentages of campus centers with coordinators and directors of faculty or instructional development cannot be made because of different population parameters. However, in 1985, Erickson's (1986) study of four-year institutions had $44 \%$ indicating an on-campus person or unit for faculty development or instructional improvement. At research universities a similar percentage appeared to hold, as well. By the Winter of 1992-93, apparently a great deal of progress had been made in establishing faculty development programs and centers within the organizational structure of a substantial majority of research universities.

\section{Summary}

The survey findings lend rather dramatic evidence to a higher level of institutional support for senior faculty renewal on research campuses than heretofore measured. Also, the survey findings suggest that 
more support is being provided to senior faculty for integrating their teaching and research roles, particularly now as an attitudinal shift toward rewarding and encouraging good teaching and improving undergraduate education is taking hold on a number of research campuses. Furthermore, there appears to be a renewed emphasis on community and collegiality as hallmarks of distinguished service and scholarship.

At research universities, senior faculty with their accumulated knowledge, experience, and seasoned wisdom are best prepared to contribute to this kind of integrated scholarship and service as part of a more multifaceted career. By providing program initiatives which have as their goal the integration of teaching, research, and service responsibilities for senior faculty, research universities are charting a new course for how the next generation of faculty will be assessed and rewarded for their work, as well.

According to Erikson's (1982) landmark theory of human development, the principle task of adult life is the quest for a sense of generativity -a need to produce something or contribute something that will outlive oneself, to leave a legacy. Faculty developers can assist senior faculty members in achieving their unique individual legacy by promoting risk-taking and role change as part of their continuing professional development. They can engage senior faculty in a challenging agenda in concert with broader institutional and societal goals through growth contracting and career reexamination. Vital and productive senior faculty are the life blood of any college or university. Faculty developers need to nurture and strengthen all those who sustain the academic enterprise that we know as higher education.

\section{References}

Albright, M. J., \& Graf, D. L. (1992). Instructional technology and the faculty member. In M. J. Albright \& D. L. Graf (Eds.), New directions for teaching and learning: Teaching in the information age: The role of educational technology, No. 51 (pp. 7-15). San Francisco: Jossey-Bass.

Astin, A. E., \& Baldwin, R. G. (1991). Faculty collaboration: Enhancing the quality of scholarship: ASHEERIC higher education report, No. 7. Washington, DC: Association for the Study of Higher Education.

Bader, J. E. (1988). “Uncapping” in higher education: A primer. Educational Gerontology, 14, 481-495. 
Baldwin, R. J. (1984). The changing developmental needs of an aging professoriate. In C. M. Mehrotra (Ed.), New directions for teaching and learning: Teaching and aging, No. 19 (pp. 45-56). San Francisco: Jossey-Bass.

Baldwin, R. J., \& Blackburn, R. T. (Eds.). (1983). New directions for institutional research: College faculty: Versatile human resources in a period of constraint, No. 40. San Francisco: Jossey-Bass.

Blackwell, J. E. (1989). Mentoring: An action strategy for increasing minority faculty. Academe, 75(5), 814.

Boice, R. (1992). Lessons learned about mentoring. In M. D. Sorcinelli \& A. E. Austin (Eds.), New directions for teaching and learning: Developing new and junior faculty, No. 50 (pp. 51-61). San Francisco: Jossey-Bass.

Boyer, E. L. (1990). Scholarship reconsidered: Priorities of the professoriate. Princeton, NJ: The Carnegie Foundation for the Advancement of Teaching.

Carnegie Foundation for the Advancement of Teaching. (1987). A classification of institutions of higher education. Princeton, $\mathrm{NJ}$ : Author.

Centra, J. A. (1976). Faculty development practices in U.S. colleges and universities (Project Report, No. 76-30). Princeton: Educational Testing Service.

Centra, J. A. (1993). Reflective faculty evaluation: Enhancing teaching and determining faculty effectiveness. San Francisco: Jossey-Bass.

Chronister, J. L. (1990). Designing options for early retirement. In J. H. Schuster, D. W. Wheeler, \& Associates, Enhancing faculty careers (pp. 139-164). San Francisco: Jossey-Bass.

Craver, C. B. (1990). Implications of the elimination of mandatory retirement for professors. Journal of College and University Law, 16(3), 343-372.

Crawley, A. L. (1990). Meeting the challenge of an aging professoriate: An opportunity for leadership. To Improve the Academy, 9, 231-243.

Crawley, A. L. (1995). Senior Faculty and the end to mandatory retirement: Uncovering age-bias in academe, Journal of Staff, Program and Organization Development, 13(1), 19.

Crawley, A. L. (in press). Senior faculty renewal at research universities: Implications for academic personnel policies. Innovative Higher Education., 20(2).

El-Khawas, E. (1991). Senior faculty in academe: Active, committed to the teaching role, Research Briefs, 2(5).

Erickson, G. (1986). A survey of faculty development practices. To Improve the Academy, 5, $182-196$.

Erikson, E. H. (1982). The life cycle completed. New York: W.W. Norton.

Finkelstein, M. J., \& Jemmott, N. D. (1993). The senior faculty: Higher education's plentiful yet largely untapped resource. In M. J. Finkelstein \& M. W. LaCelle-Peterson (Eds.), New directions for teaching and learning: Developing senior faculty as teachers, No. 55 (pp. 95-98). San Francisco: Jossey-Bass.

Franke (1993). Marking the end of mandatory retirement. Academe, $9(3), 88$. 
Hammond, P. B., \& Morgan, H. P. (Eds.). (1991). Ending mandatory retirement for tenured faculty: The consequences for higher education. Washington, DC: Committee on Mandatory Retirement in Higher Education, National Research Council, National Academy Press.

Hosokawa, E. P. (1990). Adapting employee assistance programs for academic settings. In J. H. Schuster, D. W. Wheeler, \& Associates, Enhancing faculty careers (pp. 123-138). San Francisco: Jossey-Bass.

Johnsrud, L. K. (1994). Enabling the success of junior faculty women through mentoring. In M. A. Wunsch (Ed.), New directions for teaching and learning: Mentoring revisited: Making an impact on individuals and institutions, No. 57 (pp. 53-64). San Francisco: Jossey-Bass.

Kurfiss, J., \& Boice, R. (1990). Current and desired faculty development practices among POD members. To Improve the Academy, 9, 73-82.

Lewis, K. G., \& Povlacs (Eds.). (1988). Face to face: A sourcebook of individual consultation techniques for faculty/ instructional developers. Stillwater, OK: New Forums Press.

Lozier, G. G., \& Dooris, M. J. (1991). Faculty retirement projections beyond 1994. Boulder, CO: Western Interstate Commission for Higher Education.

National Center for Educational Statistics (1990). 1988 National survey of postsecondary faculty. Washington, DC: Office of Department Educational Research and Improvement. Washington, DC: United States Department of Education.

North, J. D. (1991). Faculty vitality: 1990 and beyond. To Improve the Academy, 10, 9-18.

Nyquist, J, Abbott, R. D., \& Wulff, D. H. (Eds.). (1989). New directions for teaching and learning: Teaching assistant training in the 1990s, No. 39. San Francisco: JosseyBass.

Rice, E., \& Finklestein, M. (1993). The senior faculty: A portrait and literature review. In M. J. Finkelstein \& M. W. LaCellePeterson (Eds.), New directions for teaching and learning: Developing senior faculty as teachers, No. 55 (pp. 7-21). San Francisco: Jossey-Bass.

Schuster, J. H. (1990a). Faculty issues in the 1990s: New realities, new opportunities. In L. W. Jones \& F. A. Nowotny (Eds.), New directions for higher education: An agenda for a new decade, No. 70 (pp. 33-41). San Francisco: Jossey-Bass.

Schuster, J. H. (1990b). The need for fresh approaches to faculty renewal. In J. H. Schuster, D. W. Wheeler, \& Associates, Enhancing faculty careers (pp. 119). San Francisco: Jossey-Bass.

Schuster, J. H. (1993). Preparing the next generation of faculty. In L. Richlin (Ed.), New directions for teaching and learning: Preparing faculty for new conceptions of scholarship, No. 54 (pp. 27-38). San Francisco: Jossey-Bass.

Seldin, P. (1991). The teaching portfolio: A practical guide to improved performance and promotion/tenure decisions. Boston: Anker Publishing.

Seldin, P. (1993). How campuses evaluate professors, 1983 v. 1993. AAHE Bulletin, 46(2), 7-12. 
Wheeler, D. W., \& Schuster, J. H. (1990). Building comprehensive programs to enhance faculty development. In J. H. Schuster, D. W. Wheeler, \& Associates, Enhancing faculty careers (pp. 275-297). San Francisco: Jossey-Bass.

Western Interstate Commission for Higher Education. (1992). Bringing into focus the factors affecting faculty supply and demand. Boulder, CO: Author 